\title{
A TERÜLETFEJLESZTÉSI TÖRVÉNY UTÁN EGY ÉV TANULSÁGAI ÉS TAPASZTALATAI ${ }^{1}$
}

\section{(A Year after the Regional Development Act: Lessons and Experiences)}

\author{
(BÁN IMRE - ORMOSY VIKTOR) \\ A területfejlesztésrōl és területrendezésröl szóló \\ 1996. évi XXI. törvény
}

A szakma által régóta várt jogszabály, a területfejlesztésröl és a területrendezésrö] szóló 1996. évi XXI. törvény létrejöttét az államigazgatásnak a rendszerváltást kővető szemléletváltása tette lehetővé, és az Európai Közősséghez való csatlakozási szándék tette igazán időszerüvé. A törvény létrehozásának legsürgetőbb indoka az volt, hogy a társadalmi és gazdasági átalakulás során a differenciáló, szelektáló gazdasági erők és az ezeket támogató szabályozás hatására felerősödtek a területi egyenlötlenségek. A modern gazdasági struktúrák, szervezeti- és tulajdonformák egyenetlen elterjedése miatt növekedett a fejlettségi különbség a nyugati és a keleti országrészek között. Súlyos helyzetbe kerültek a társadalmi és gazdasági szempontból elmaradott térségek és az állami nagyiparra alapozott, tradicionálisan ipari jellegü térségek. A központi eszkőzők, ezen belül a területfejlesztési pénzügyi támogatások, a kormányzati fejlesztési programok sem tudták érdemben befolyásolni a kedvezötlen folyamatokat.

Ennek csak részben volt oka a források elégtelensége és a központi források nem kellő összehangoltsága. A regionális válságkezelés nemzetkőzi tapasztalatai azt mutatják, hogy a központi akciók önmagukban nem lehetnek sikeresek. A válsághelyzetek megoldása csak a különbőző problémákat komplex módon kezelō, a helyi sajátosságokat messzemenően figyelembevevő, a pozitiv térségi kezdeményezéseket felkaroló helyi, térségi stratégia kialakitásán és megvalósitásán alapulhat. Mindez a területfejlesztés döntési szintjeinek decentralizálását tette szilkségessé.

A jövőben az állam fö feladata: a megfelelő közgazdasági feltételrendszer megteremtése, a területi intézményrendszer kiépülésének támogatása lesz, miközben a konkrét cselekvési programok kidolgozását és megvalósítását - a központi koordináció és ellenőrzés mellett - a térségi szereplőknek engedi át.

A területfejlesztésről és területrendezésröl szóló törvény a decentralizáció, a partnerség és a demokratikus nyilvánosság alapelveire épül. A demokratikus nyilvánosság szerepének nővekednie kell a regionális politikában, amelynek újszerüsége éppen a helyi erőforrások bevonásában és a nagyobb társadalmi támogatottságban rejlik.

A területfejlesztés általános távlati céljai:

- az ország egészének arányos fejlesztése,

- a lakosság életfeltételeinek javítása;

- a társadalmi és gazdasági esélykülönbségek csőkkentése; 
- a régiók, településtípusok civilizációs és infrastrukturális feltételeinek közelítése;

- az elmaradott, hátrányos térségek, települések helyzetének javitása, problémáinak kezelése.

A területfejlesztési politika úgy kíván az ország gyorsabb és hatékonyabb fejlödéséhez hozzájárulni, hogy nem a közvetlen üzleti jövedelmezöség elérését tüzi ki céljaként, hanem az ahhoz szükséges szolgáltatási, infrastrukturális és információs feltételek kialakitását tekinti elsődlegesnek. Mindezek érdekében meg kell teremteni a termelési tényezök, a munkaerő, a tőke, a szakértelem, a know-how ésszerü térbeli mobilitásának feltételeit, hozzá kell járulni az ország modernizálásához, biztosítani a fenntartható fejlődést a környezeti adottságokkal és terhelhetőséggel összhangban. A fenntartható fejlődés elve részben környezetvédelmi követelményeket takar, de érvénye azon túl is terjed, kiterjed a jövő generációiért viselt felelösségre is.

A területfejlesztésröl és területrendezésröl szóló törvény nyomán jelentös változások mentek végbe a területfejlesztési politika döntési mechanizmusában. Ezek az intézményrendszer decentralizációját, demokratizálását és koordinációs szerepének növelését jelentik.

A területfejlesztés célrendszere komplex eszközrendszer kialakítását igényli, amelynek egyik fontos eleme a közvetlen pénzügyi támogatás. Az országgyülés és a kormány figyelemmel kísérve és értékelve a területi, gazdasági és társadalmi folyamatokat, meghatározza a támogatások irányelveit és a pénzügyi eszközök felhasználásának szabályait. A területfejlesztés gazdasági fejlödésre gyakorolt hatása felfedezhetö a központi költségvetés tervezése, az egyes ágazatok fejlesztési programjainak kidolgozása és koordinációja terén is.

\section{A Területfejlesztési Törvény érvényesülése a gyakorlatban}

A tanácsok a decentralizálandó pénzeszközök nagyságrendjét rögzitö, végleges formában 109/1996.(VII.16.) számú, illetve azok felhasználási szabályait és a pályázati kírás alapvető feltételeit megállapító 107/1996. (VII.16.), valamint 108/1996.(VII.16.) számú jogszabályok elöírásainak megfelelően komolyabb nehézségek nélkül megfeleltek a megszabott határidöknek.

Már a pályázati kiírás, illetve a döntés-elökészités szakaszában felmerült számos olyan kérdés és kritika, amelyek folyamatosan felszínen maradtak, és amelyekre az 1997. évi szabályozás kialakítása során lehet majd válaszokat találni. Több önkormányzat sérelmezte, hogy az alkalmazott mutatórendszer - a térségi központ viszonylag kedvezőbb paraméterei miatt - az egyébként súlyos helyzetben lévö települések támogatását nem teszi lehetővé. Ennek megfelelöen az 1997. évben a megyeszékhelyek mutatói már nem fogják hátrányosan érinteni a központi kistérség egyéb településein megvalósítandó beruházások támogathatóságát.

A másik általánosítható probléma a kistérségi besorolással, egyidejủleg a besorolás megváltoztatásának igényével függött össze. Bár a statisztikai kistérségek határvonalainak igényektöl függö, folyamatos átrajzolása szakmailag nem elfogadható, bizonyos módosítások végrehajtásának jogosságát szakértöi szinten sem kérdőjelezték meg. Ennek rendezésére is még ez évben sort kerít a Központi Statisztikai Hivatal a Környezetvédelmi és Területfejlesztési Minisztériummal 
együttmüködve. A felülvizsgálat nem eredményezheti azonban, hogy a statisztikai kistérségi rendszer területe azonos legyen az önkormányzati társulások területével, mert az önkormányzatok nem kötelesek társulásba lépni, másfelöl viszont ugyanaz az önkormányzat több társulásnak is tagja lehet. Biztositani kell a rendszer stabilitását hosszabb időtávra.

Vita tárgya volt a decentralizált területfejlesztési pénzeszközök egyes megyékre jutó konkrét összege is. A kifogás nem a mutatók alkalmazásával szemben fogalmazódott meg, hanem inkább az merült fel, hogy e paraméterek milyen súllyal szerepeljenek a decentralizált területfejlesztési pénzeszközök megyék közötti arányainak megállapításánál. Erre a jelenleg parlamenti tárgyaláson lévö - a területfejlesztési támogatások, valamint a decentralizáció irányelveiröl és a kedvezményezett térségek besorolásának feltételrendszeréröl szóló - országgyülési határozathoz kapcsolódó kormányrendeletek egyeztetése során kell majd megoldást találni. (Azóta a Parlament a határozatot már elfogadta.)

\section{A területfejlesztési tanácsok müködésének tapasztalatai}

A döntések szakmai elökészitésében jelentös szerepet vállaltak a tanácsok tagjait delegáló szakmai szervezetek, illetve a legtöbb helyen a Magyar Államkincstár helyi fiókszervezetei is.

A megalapozottnak mondható döntés-elökészítés ellenére többnyire komoly vita kísérte a pénz felosztását, és gyakran elöfordult, hogy informális egyeztetéseket is tartottak a tanácsok tagjai. Részben ezeknek a megbeszéléseknek az eredménye, hogy október első napjaira szinte mindenhol megszülethettek a megyei keretek felosztásáról hozott döntések. Vitát váltott ki a tanácsoknál, hogy sok beruházást támogassanak-e az igényelt támogatási mértéknél alacsonyabb összeggel, vagy kevesebbet, de a kért támogatás szinte teljes nagyságrendjének odaitélésével. Többségében az elöbbi álláspont érvényesült.

Mindkét kormányrendelet lehetöséget adott a pályázati feltételektől való eltérésre, amelyhez miniszteri felmentés volt szükséges. Ezzel valamennyi megyében éltek a tanácsok. Leginkább a már megkezdett beruházások támogatásának engedélyezését kérték, illetve a saját forrás minimálisan elöirt 20\%-os nagyságrendjétöl való eltérésre támasztottak igényt a pályázók, de előfordult az ismételt támogatás, illetve a támogatás együttes összegének megváltoztatása iránti kérelem is. A felmentéshez folyamodók nagy száma azt jelzi, hogy a kormányrendeletek 1997. évi megalkotásánál ezen a téren is szükséges a jogszabályok eddigi elöírásainak módosítása. A döntéseket követően a legfontosabb feladat a támogatási szerzödések mihamarabbi megkötése volt. Ez az időszak számított a területfejlesztésröl és területrendezésről szóló törvény elfogadását követően kialakult decentralizált döntéshozatali rendszer legkritikusabb szakaszának. Több pályázó nem tudta vállalni az alacsonyabb támogatási mérték mellett a beruházás elindítását, így szinte valamennyi megyében felszabadultak pénzeszközök. A tanácsok a probléma kezelésére a legtöbb megyében tartaléklistákat állítottak fel, amelyen a forráshiány miatt elutasított pályázatok szerepeltek, és az el nem költött források nagyságrendjétől függően általában e listák vezető helyein szereplö pályázatok váltak automatikusan kedvezményezetté. A másik eszköz a korábban alacsonyabb hozzájárulást kapott pályázatok támogatási arányának növelése volt. 
Eröteljes igényként merült fel, hogy - a központi költségvetési forráselvonást elkerülendő - kormányzati, mindenekelőtt pénzügyminisztériumi állásfoglalás szullessen arra az esetre, ha képződik 1997-re áthúzódó maradvány. A Pénzügyminisztérium januárban alakította ki végleges véleményét, amely alapján nem vonhatóak el egyrészt a szerződéssel lekötött támogatások, másrészt azok a pénzeszközök, amelyekre ugyan még nem kötöttek szerződést, de a tanács nyilvánosságra hozta az érintett kedvezményezettek névsorát.

\section{A döntések területfejlesztési hatásai}

A rövid pályázati időszak ellenére a két támogatási rendszer felhívására - kőzel azonos arányban - összességében 3300 pályázó nyújtott be támogatási igényt. A megyei területfejlesztési tanácsok a 4,7 Mrd Ft decentralizált területfejlesztési célelöirányzat 98\%-áról - azaz 4,6 Mrd Ft-ról - döntöttek. A különbözetet a döntések végrehajtása során bekövetkezett változások eredményezték.

$\mathrm{Az}$ 1997. évre áthúzódó kőtelezettség vállalás $1,31 \mathrm{Mrd} \mathrm{Ft}$, amely az 1996. évi keret 28\%-a. (A 107/1996. (VII.16.) kormányrendelet 30\%-ban húzta meg a határt.) Az 1998. évre vállalt 214,4 M Ft-os kötelezettséggel együtt ez az arány alig $32,3 \%$, azaz alatta marad a jogszabályban elöírt felső mértéknek, amely $40 \%$ volt. Összesen tehát a tanácsok 6,01 Mrd Ft támogatásról döntöttek, amely több, mint ötször akkora - mintegy 32,0 Mrd Ft összköltségü - beruházás megvalósítását segíti elő.

A kormányrendelet céljainak megfelelően az 1996. évi keret három legnagyobb arányt mutató támogatása, az 1996. évi keret mintegy 89-90\%-át köti le:

- munkahelyteremtő és -megtartó beruházások, 1,95 Mrd Ft (43,4\%);

- termelö infrastrukturális beruházások, 1,59 Mrd Ft (35,4\%);

- különböző - kistérségi, megyei, helyi vállalkozásösztönző, stb. fejlesztési programok elkészitését $0,46 \mathrm{Mrd}$ Ft-tal $(10,2 \%)$ segítették elŏ a tanácsok.

A munkahelyteremtö-, illetve megtartó beruházások megvalósítását elsősorban vissza nem térítendő támogatásokkal segítették. Arányában nem volt jelentős (mindössze $6,6 \%$ ) a visszatéritendő juttatás és elhanyagolható arányú $(0,6 \%)$ a kamattámogatás. A fenti arányok kiegyensúlyozottabbá tétele érdekében megfontolandó, hogy a visszatérítendõ támogatások kőzvetlenül álljanak visszatérítésúket kővetōen - a tanácsok rendelkezésére.

A termelö infrastrukturális beruházásokon belül elsősorban a szennyvízberuházások (az összes 1996. évi termelő infrastruktúra-támogatás 37,4\%-a), a gáz $(24,8 \%)$, valamint az utak, kerékpárutak (14,2\%) kivitelezéséhez, illetve befejezéséhez, juttatott hozzájárulás mértéke volt jelentősnek mondható.

A munkahelyteremtő beruházásokat elsősorban Szabolcs-Szatmár-Bereg $(88,1 \%)$, Borsod-Abaúj-Zemplén $(68,9 \%)$, illetve Heves $(61,8 \%)$ támogatta, míg Zala $(11,4 \%)$, Vas $(9,8 \%)$, és Fejér $(1,2 \%)$ megyék kevésbé preferálták ezt a célt. A termelö infrastruktúrára legtöbbet Zala $(83,4 \%)$, Vas $(80,6 \%)$, illetve Fejér $(70,3 \%)$ megyék fordították. Borsod-Abaúj-Zemplén és Szabolcs-Szatmár-Bereg megyék ilyen célt egyáltalán nem támogattak. A decentralizált, területi kiegyenlítő támogatások terhére a Területfejlesztési Tanácsok gyakorlatilag az elöirányzat teljes összegét lekötötték. (A maradvány mindössze 4,4\%.) Ennek a forrásnak a terhére megközelítőleg 1,3 Mrd Ft nagyságrendü kötelezettséget vállaltak a tanácsok, amely a jövő évi keret 29,9\%-a. Ez az összeg 1998-ra 256,1 ezer Ft, amely a keret mindössze 5\%-a. A kötelezettség-vállalások együttes nagyságrendje $34,9 \%$, azaz a 
tanácsok jelentősen alatta maradtak a 108/1996. Kormányrendeletben megszabott felső határnak. Az összességében 6,6 Mrd Ft-os támogatás, mintegy $30 \mathrm{Mrd} \mathrm{Ft}$ nagyságrendủ beruházás megvalósitásához járul hozzá, ami több mint négyszeres indukáló hatást jelent. A támogatások több, mint $75 \%$-át költötték termelö infrastrukturális beruházások megvalósítására. Ezen belül különösen a víz, szennyvíz, illetve a gázhálózat épitésére fordítottak nagy összeget, de az úthálózatépitést is támogatták (20\%). A termelö infrastruktúrán belül ezek együttesen teszik ki a támogatások $85 \%$-át.

\section{A Magyar Államkincstárral való együttmüködés tapasztalatai}

A támogatási szerződések megkötése kevésbé volt problematikus a folyósitás másik alapfeltételét jelentő finanszírozási szerződésekhez képest, ezért indokolt ennek tapasztalatait is áttekinteni. A MÁK - a kiirt tender elnyerését követően - és a KTM hosszas egyeztetés után decemberben kötötte meg a megállapodást a szolgáltatás tartalmáról és feltételeiröl. Ez a Kincstárnak jelentős - formai, pénzügyi - szüröfunkciót biztosít a döntés elökészítésben, lebonyolitásban, ellenörzésben. Nem helyettesítik egymást a Kincstár, illetve a megyei munkaszervezetek, hasznos tevékenységük egymásra épül. A Kincstár megyei szervezetei is későn kapcsolódtak be a munkába. Több megyében csak a döntések, söt egyes esetekben csak a szerzödéskötések után kezdtek foglalkozni a pályázatokkal. A késôi kapcsolatfelvétel egyik „eredménye”, hogy a pályázatokkal benyújtott mellékletek egy része aktualitását vesztette, ezért újra be kellett szereztetni a pályázókkal.

A területfejlesztési tanácsok, mint intézményrendszer, szervesen kapcsolódnak mind a kistérségi, mind az országos szervezetekhez. Ezek müködése szemléletében megelözte azt a költségvetési, tervezési, döntési mechanizmust, amely kiszolgálja öket. Alapvető koordinációs problémaként értékelhető, hogy a kistérségek megyei fejlesztési tanácsokkal folytatott vitája, egyeztetései nem a Kincstár által elözetesen megvizsgált formai, pénzügyi követelményeknek megfelelö pályázatok alapján, a szelektált pályázatok esetében történt, hanem elöször született a "megegyezés", majd a megkötőtt támogatási szerződéseket a Kincstár bírálta el.

A szervezeti együttmüködés és a szabályozás egyik fontos tapasztalata, hogy csak az általános pénzügyi, jogi, stb. követelményeknek megfelelő pályázatok közötti differenciálással lehet jó döntést hozni a támogatásokról, a decentralizált források felhasználásáról. A másik nagyon fontos tapasztalat, hogy a megyei tanácsoknak minél hamarabb átfogó megyei koncepcióra van szükségük annak érdekében, hogy az ennek alapján kialakított programok megvalósítására koncentrálva adjanak vagy utasítsanak el adott esetben formailag, pénzügyileg megfelelö pályázatokat is.

Hosszabb távon két jelentős feladat megoldása áll még a területfejlesztés hazai gyakorlata elött. Egyrészt, az állami források koordinált, összehangolt felhasználásának kell megteremteni az intézményi, jogszabályi feltételeit, másrészt, ezzel összefüggésben - a nemzetközi források jobb elérhetősége érdekében - a programfinanszirozás tényleges gyakorlatának bevezetésére kell a jövö erőfeszítéseit koncentrálni.

\section{Jegyzetek}

${ }^{1}$ Az elöadás $A$ területi tervezés új kihívása: a területfejlesztési koncepció c. konferencián hangzott el. (Győr, 1997. április 3-4.) 